\title{
HOW THE DOMAIN NAME SCUFFLES ARE ROCKING THE FOUNDATIONS OF TRADE MARK LAW
}

\author{
Rachel Keane*
}

The central proposition of this paper is that it is no longer valid to assert that the only and proper function of the trade is to denote the source of the product to which it is affixed. Trade marks are being employed in many diverse ways. In the age of mass media, trade marks may provide the key to marketing successfully. The dilution doctrine has developed in recognition of the potential value of a trade mark to tis owner. Anti-dilution provisions, as far as they go, do provide a useful tool in protecting the trade mark itself. However, as technology continues to advance, so does the trade mark function. The so-called domain name disputes, primarily in the United States are evidence of this claim. Not only have the decisions in these cases furthered the development of the trade mark legislation, they have demonstrated the inadequacies of the current trade mark legislation and the desperate need for reform. These inadequacies are examined and reform is proposed. Finally, the paper assesses the desirability of allowing the further expansion of the trade mark. It is submitted that the proper expansion of the trade mark should not be resisted.

\section{INTRODUCTION}

The protection of trade marks is the law's recognition of the psychological functions of symbols. If it is true that we live by symbols, it is no less true that we purchase goods by them. A trade mark is a merchandising short-cut which induces a purchaser to select what he wants, or what he has been led to believe he wants. The owner of a mark exploits this human propensity by making every effort to impregnate the atmosphere of the mark with the drawing power of a congenial symbol, the end is the same - to convey the mark, in the minds of potential customers, the desirability of the commodity upon which it appears. Once this is attained, the trade mark owner has something of value. ${ }^{1}$

* This paper was submitted in fulfilment of the LLB(Hons) requirements at Victoria University in 2000.

1 Mishawaka Rubber and Woollen Mfg Co v SS Kresge Co (1942) 316 US 203, 205. 
This is the story of a struggle between two super-powers of the modern trading environment. On one side is the veteran trade mark. Opposing it is the domain name.

The tension can be succinctly stated. In traditional theory, trade marks are marks on products which enable the consumer to identify their source. Traditionally they are not regarded as having intrinsic worth. Domain names are addresses on the Internet. It is imperative to a business wishing to trade on-line that they have a domain name which will be obvious to the web-user. Trade marks naturally fulfil this requirement; a trade mark will often already be synonymous with the company and the goods in respect of which it is registered. Competing users of the same trade mark and trade mark pirates are racing to be the first to register their or another's marks as domain names. This provides a breeding ground for disputes.

However the real tension is not between the trade mark owners and the trade mark pirates; it is between the trade mark and the domain name. The enforcement of trade mark rights against the person who registers another's trade mark as a domain name calls for the courts to acknowledge that trade marks are of a greater and different value to their owners than has traditionally been accepted. It is also demands recognition that trade marks are susceptible to new and varied types of damage.

The more recent development of an action for dilution of a trade mark does, to a certain extent, recognise the potential value of a trade mark itself. This action has been put to use by aggrieved trade mark owners in domain name cases in the United States and Britain with varying degrees of success. However, the courts have had to turn somersaults within the wording of the anti-dilution provisions to bring the actions of the defendants within their ambit.

It is the submission of this paper that the trade mark function is shifting further and further from its initial conception and that the development for an action for dilution of a trade mark is evidence of this shift. It is further argued that the issues raised by domain name disputes present a novel challenge to trade mark legislation; not only is the dilution action not robust enough in its present form to meet this challenge, but domain name disputes are instrumental in the continuing evolution of the trade mark.

Part I of the paper will set up the bases for later argument. This section will identify the traditional conceptions of the trade mark function and the bases for their protection and will discuss the view that there is no intrinsic worth in a trade mark. The implications of these conceptions for the structure of trade mark law will be examined.

Part II will examine the development of the action for dilution of a trade mark. It will be argued that this attempt to protect the reputation and distinctiveness of a mark is recognition of the growing acceptance that trade marks are capable of having an intrinsic worth. 
Part III will discuss the tension inherent in using trade mark law to resolve domain name disputes. The main case law in the area will be presented as evidence of this tension. It will be argued that the reasoning in the domain name cases is indicative of the acceptance that trade marks are of a greater value than previously accepted and further, that the decisions themselves are having a wider impact on the continuing evolution of the trade mark function.

Part IV will assess the efficacy of current trade mark legislation in dealing with the trade mark in its modern form. The domain name cases will be presented as symptomatic of the inadequacies of current trade mark legislation. It will propose some changes within the existing framework which would recognise the increasing need to protect the trade mark itself, regardless of the goods in respect of which it is registered.

Part V will involve taking a step back from the analysis and will pose some fundamental questions as to the desirability of the shift in the trade mark function and the trend towards providing increased rights in trade marks.

\section{THE ROOTS OF TRADE MARK LAW}

\section{A The Traditional Boundaries of the Trade Mark Function and the Bases and Scope of Trade Mark Protection}

The trade mark has seen many stages of development since it inception in around 5000BC. This paper is concerned with the "modern" trade mark, the theory of which is considered to have consolidated by the beginning of the twentieth century. The primary and proper function of the "modern" trade mark has been described in many ways. It was concisely expressed by the Supreme Court of the United States in the leading case of Hanover Star Milling Co v Metcalf: "to identify the origin or ownership of the goods to which it is affixed". ${ }^{2}$ Pickering distinguished the rationale of the trade mark right from those of patents and copyright "which manifestly are for the purposes of reward or incentive"13:4

Rather, the trade marking of goods is protected as an emergent social phenomenon dating in its modern form from the time of the industrial revolution; the rights granted may be seen as protecting the interests of those affected by trade mark use for fear of the consequences were these interests not protected.

This theory assumes that consumers rely upon trade marks as a source of information, that is, a means of identification of a favoured product. Consumers, therefore, have a

2 Hanover Star Milling Co v Metcalf(1916) 240 US 403, 412.

3 CDG Pickering Trade marks in Theory and Practice (Hart Publishing, Oxford, 1998) 97.

4 Pickering, above n 3, 97. 
legitimate expectation that a particular trade mark will continue to signify the product with which they have been conditioned to associate it. ${ }^{5}$ This right has assumed increasing importance in the age of mass consumption and international trade, "otherwise consumers would be open to abuse by unscrupulous traders". 6 As will be seen later in this discussion, this source denoting function is constantly being challenged by the realities of modern business.

The traditional basis for the protection of trade marks is deeply entwined with the trade mark function. Early cases in equity indicated that a trade mark was a legal right, akin to a property right, while the common law focussed on the question of deceit. ${ }^{7}$ Modern trade mark protection is conferred to afford the owner of the mark certain rights to protect unfair competition and diversion of custom and to protect the consumer from deception as to the source of products. ${ }^{8}$ Protection does not recognise an intrinsic worth in a trade mark, nor does it treat a mark as property.

The scope of trade mark protection derives directly from the traditional conception of the trade mark function and the bases for protection described above. In New Zealand trade marks are protected through a system of registration. The proprietor of a registered trade mark shall have the exclusive right to the use of the trade mark in relation to the goods in respect of which it is registered. The proprietor also has the right to restrain certain infringing uses of the trade mark. The rights of a registered proprietor in a trade mark are infringed where a third party uses a sign, in the course of trade, which is either identical to, or similar to, the registered mark in relation variously to goods and/or services which are identical or similar to the goods and/or services in respect of which the mark is registered. ${ }^{9}$ For there to be infringement, the offending mark has to have been used "in such manner as to render the use of the sign likely to be taken... as being use as a

5 Pickering, above $\mathrm{n} 3,99$.

6 Pickering, above n 3, 100. It should be noted, however, that the consumer protection theory behind the rationale for protection of trade marks is not faultless. It may serve to prevent the illegitimate use of marks by other traders, thus causing consumer confusion, but there is nothing to prevent a manufacturer employing cheaper production methods and thus producing a lower quality product than that to which the customer has become accustomed. It is claimed that the market will respond, but in order to find out that a formerly satisfactory product has ceased to be so, consumers must incur expense .

7 In Millington $v$ Fox (1838) 3 Myl \& Cr 338 a remedy was allowed in equity, even though there had been no fraudulent intent. Conversely, the approach under the common law, starting with Sykes $v$ Sykes (1824) 3 B \& C 543 required proof of deliberate deceit.

8 See, for example, the discussion of the function of the trade mark in Staniforth Ricketson The Law of Intellectual Property (The Law Book Company, Sydney, 1984) 603.

9 Trade Marks Act 1953, s 8. 
trade mark", 10 or, in certain circumstances, as "importing a reference to some person having the right either as proprietor or as registered user to use the trade mark or to goods with which such a person is connected in the course of trade". ${ }^{11}$ It is clear from these provisions that the protection offered in New Zealand is aimed at preventing consumer confusion and illegitimate diversion of trade. These provisions do not protect the trade mark itself.

\section{B The Implications of the Traditional Boundaries for the Structure and Development of} Trade Mark Law

The conception that a trade mark serves to denote the source of a product and to prevent consumer deception and confusion has certain far reaching implications. Schechter claimed in 1927 that these obsolete conceptions served only to hamper the proper development of the trade mark. ${ }^{12}$

The source denoting theory is to deny that the trade mark is capable of having an intrinsic worth. It is to place unnatural restrictions on the natural development of the trade mark in the modern age. It simply does not acknowledge that the trade mark is of equal, if not greater value to the producer than to the consumer. As Schechter wrote: "The principal obstruction to the development of the law in accordance with the necessities of business has been the uncertainty of those administering or commenting upon the law as to whether or not trade- marks are what they term 'property'". ${ }^{13}$ This confusion may pose difficulties in affording protection to trade marks, as while the courts are reluctant to base their relief upon a theory of protection of property, there does not seem to be an obvious alternative basis upon which to provide relief. As will be seen below, when faced with innovative and unconventional trade mark claims, the courts, without saying so much, grapple with this very issue.

10 Trade Marks Act 1953, s 8(1A)(d).

11 Trade Marks Act 1953, s 8(1A)(e).

12 Frank Schechter "The Rational Basis of Trademark Protection" (1926-1927) 40 HarvL Rev 813.

13 Schechter, above n 10, 150. 


\section{THE DEVELOPMENT OF THE DILUTION DOCTRINE IN THE UNITED STATES: EVIDENCE OF A SHIFT IN THE FOUNDATIONS}

\section{A The Development of the Dilution Doctrine ${ }^{14}$}

The trade mark has not reached a standstill. It continues to evolve. Schechter claimed in 1927 that the trade mark has assumed a function which exceeded that of merely denoting the source of a product, acting as an "agent for the actual creation and perpetuation of good will". With the advent of mass communication and international trading, producers recognise the value of a trade mark in fulfilling this function and trade marks now play a pivotal role in branding. A trade mark is treated as part of a branding package; it may have design attributes which are aimed at a certain market. A trade mark can become a symbol for the company's image. ${ }^{15}$ The trade mark is assuming a new function, and is thus becoming of greater value to the trade mark owner. It is on this premise that a dilution of trade mark action is based. Such an action recognises the commercial value and image of the mark itself: it protects the selling power of the mark.

Dilution represents a special kind of damage to the trade mark. It is damage that is completely distinct from that suffered in a traditional trade mark infringement. The concept of trade mark dilution is attributable to Schechter's seminal article in 1927 in which he proffered the protection of the distinctiveness and uniqueness of the trade mark as the only rational basis for trade mark protection. ${ }^{16}$ Schechter maintained that injury occurs to a trade mark owner whenever a trade mark is used by another, even when that use is in relation to non-competing goods. Schechter stated that the real injury in cases where the defendant was not actually diverting custom from the plaintiff was "the gradual whittling away or dispersion of the identity and hold upon the public mind of the mark or name by its use upon non-competing goods". ${ }^{17}$ He maintained that such an injury could only be gauged in light of his theory about the function of a trade mark and basis for its protection, that is the principle that "the value of the plaintiff's symbol depended in large part upon its

14 This section will primarily discuss the development of the dilution doctrine in the United States, as it is the most prominent.

15 For example, the Nike 'swoosh' and the slogan "Just Do It" were presumably designed to appeal to a certain target market. The symbol and the slogan conjure up images of a challenging and high pace lifestyle. The slogan has been reinforced by a high profile advertising campaign involving successful sports personalities. Another example of the trade mark becoming representative of the product is Coca-cola. A court has held that "the name now characterises a beverage to be had at almost any soda fountain. It means a single thing coming from a single source, and well known to the community. It hardly would be too much to say that the drink characterises the name as much as the name the drink" Coca-Cola Co v Koke Co (1920) 254 US 143, 146.

16 Frank Schechter "The Rational Basis of Trademark Protection" (1926-1927) 40 HarvL Rev 813, 825.

17 Schechter, above n $12,825$. 
uniqueness". ${ }^{18}$ Schechter's arguments were not popular and were widely dismissed. There was a reluctance to recognise a form of damage to a trade mark where there was no evidence of consumer confusion. Congress first addressed the issue of trade mark dilution in the early 1930s but did not pass the "Perkins Bill," drafted primarily by Schechter, which would have given a federal cause of action for trade mark dilution. ${ }^{19}$

The concept of trade mark dilution did not die out, but evolved in the courts. Some courts used the dilution theory and referred to Schechter's theory in their decisions, however the courts' final decisions relied upon consumer confusion. ${ }^{20}$ In 1947 Massachusetts adopted the first state anti-dilution statute. As of January 1996, twenty eight states had enacted similar anti-dilution statutes. In 1964, the United States Trademark Association added an anti-dilution component to its Model State Trademark Act. In 1995 the Federal Trademark Dilution Act was enacted. ${ }^{21}$

\section{B The Elements of Dilution}

Anti-dilution statutes aim to protect the trade mark from "blurring" or "tarnishment" and further, from any harm to its uniqueness, singularity or to its capacity to identify the source of the goods sold under it. The elements required to be proved in an action for dilution of a trade mark reflect the purpose of the protection.

\section{The mark must be famous}

The anti-dilution remedy is available to famous marks only. Factors taken into account when assessing whether a mark fulfils this requirement include the uniqueness of the mark, whether it has acquired a secondary meaning, how widely the trade mark is known, consumer awareness of the mark and the goodwill and reputation associated with the mark. $^{22}$ For example, the court in the case of Avery Dennison Corporation $v$ Sumpton ${ }^{23}$

18 Schechter, above $n$ 12, 825-6.

19 James R Hughes "The Federal Trademark Dilution Act of 1995 and the Evolution of the Dilution Doctrine - Is it a Truly Rational Basis for the Protection of Trade Marks?" (1998) Det CLMich St U L Rev 759, 762-763.

20 See, for example, Polaroid Corp v Polaroid Inc (1973) 319 F 2d 83 (7th cir) where the well established manufacturer of photographic equipment and holder of a well-known trade mark, sought to enjoin the application of the mark "Polaroid" in advertising commercial heating systems. The court found substantial instances of confusion between the two marks before it enjoined the use of the "Polaroid" mark.

21 Hughes, above n 19, 761-5.

22 Hughes, above n 19, 759.

23 Avery Dennison Corporation v Sumpton (1999) 189 F 3d 868 (9th Cir) [Avery Dennison]. This case will discussed in more detail in Part IV below. 
found that the plaintiff's trade marks were not sufficiently famous to satisfy the requirement. The court stated that the trade marks in question, "Avery" and "Dennison," had no inherent distinctiveness. Where a trade mark is primarily a surname, it must be shown that it has acquired a secondary meaning. ${ }^{24}$ The court found that the mere registration of the names on the Trade Mark register was prima facie evidence that the marks had acquired a secondary meaning required for protection against infringement and unfair competition ${ }^{25}$. However, "because famousness requires a showing greater than mere distinctiveness, the presumptive secondary meaning associated with "Avery" and "Dennison" fails to persuade us that the famousness prong is met in this case". ${ }^{26}$

\section{Dilution of the mark: the types of harm represented by dilution}

In order to be successful in an action for dilution, the plaintiff must be able to show that the defendant's use has diluted the mark. A mark may be diluted in several ways. Originally, dilution was considered to occur through "blurring" or "tarnishment" of the plaintiff's mark. The "blurring" theory seeks to protect the uniqueness of the trade mark by preventing subsequent users from employing marks which are identical or substantially similar to that of the original user, even on non-competing goods. The essence of this theory is that the continuous use of trade marks which are similar to those of the subsequent user dilutes the uniqueness of the mark, eventually destroying all uniqueness associated with the mark. This type of harm was neatly encapsulated by Frank Schechter in the following statement:

if you allow Rolls Royce restaurants, and Rolls Royce cafetarias, and Rolls Royce pants, and

Rolls Royce candy, in ten years you will not have the Rolls Royce mark anymore.

The second traditional form of harm by dilution, "tarnishment", represents a harm to the "positive, quality-connoting associations the holder has laboured to create through advertising and promotion". ${ }^{27}$ Put simply, it represents a harm done to the reputation and good will of a trade mark holder as symbolised by the trade mark. Tarnishment may occur where another manufacturer produces defective products bearing the trade mark of the original user, thus creating the risk that public dissatisfaction with the product will tarnish the original user's mark and detract from its goodwill. This occurred in the Tiffany case ${ }^{28}$

24 Avery Dennison, see above n 23, 877.

25 Avery Dennison, above n 23, 877.

26 Avery Dennison, above n 23, 877.

27 Elliot B Staffin "The Dilution Doctrine: Towards a Reconciliation with the Lanham Act" (1995) 6 Fordham IntelLProp Media \& Ent LJ 105, 131.

Tiffany $v$ The Boston Club Inc (1964) 231 F Supp 836 (Mass). 
where Tiffany, the renowned New York jeweller, brought suit to prevent the use of its mark "Tiffany" by a Boston area bar and restaurant. The court found that the defendant's bar ran the risk of detracting from "Tiffany's" established reputation and goodwill. The court cited the fact that the defendant's restaurant provided services, "the quality of which was not established as outstanding" and which continued to decline over time. The court also cited the fact that the defendant's advertisements detracted from the public image of Tiffany's and that the defendant sponsored a radio programme of questionable quality. Other examples of tarnishment have occurred where trade marks have been used in association with unwholesome images. ${ }^{29}$ A balance in these cases must be struck between protecting the reputation of the trade mark and freedom of expression. ${ }^{30}$

The Federal Dilution Act of 1995, which amended the Lanham Act 1946 introduced a third, new type of harm. It defines dilution as:

the lessening of the capacity of a famous mark to identify and distinguish goods or services,

regardless of the presence or absence of -

(1) competition between the owner of the famous mark and other parties, or

(2) liklihood of confusion, mistake or deception

This new definition of dilution was relied upon in Panavision International, LP, $v$ Toeppen $^{31}$ [Panavision], where the court stated that it was no longer necessary to rely on traditional definitions of dilution, such as tarnishment and blurring: Toeppen's conduct in registering Panavision's mark as a domain name diminished the capacity of Panavision's marks to identify and distinguish Panavision's goods and services on the Internet and this was sufficient to constitute dilution for the purposes of the Lanham Act. ${ }^{32}$

\section{What are the Assumptions About Trade Mark Law that have Underpinned the Development of the Dilution Action?}

The development of the action for dilution of a trade mark appears to defy completely the notion that there is no intrinsic worth in a trade mark. The acceptance that a trade mark may suffer this type of injury is acceptance that trade marks have a power beyond

29 For example in Chemical Corp of America v Anheuser-Busch (1962) 306 F 2d 433 (5th Cir) where the court held that the holder of the registered trade mark "Where there's life...there's Bud" used in sale of "Budweiser" beer, was entitled to enjoin the use of a slogan "Where there's life...there's Bugs" in the sale of a combined floor wax and insecticide. The court found that there were definite negative connotations associated with bugs and Anheuser-Busch's food products. This will be discussed in greater detail in Part $\mathrm{V}$ below.

31 Panavision International LP v Toeppen (1998) 141 F 3d 1316 (9th Cir) [Panavision].

32 Panavision, above n 31, 1326. 
their ability to distinguish the source of goods or services. In a revisitation of Schechter's 1927 article, Elizabeth Bannon claimed that: ${ }^{33}$

A strong distinctive trademark may become a symbol of consumer loyalty and goodwill rather than merely an indicator of supplier identity. It is the trade mark's property rights in that goodwill that are usurped when dilution takes place

Bannon claimed that dilution was analogous to the situation in the field of real property where a second party continuously passes over the owner's property. After a period of time, the second party may claim prescriptive rights allowing it right of continuous passage over the property. This results in the owner losing the full right to control his property: ${ }^{34}$

Similar to the slowly maturing easement, dilution results in a subtle undermining of a trademark's delicate hold on the public mind and to its value

Furthermore, dilution appears to protect the investment made in a trade mark by its owner. If it is considered that dilution may only occur where a trade mark is sufficiently famous and original, it must follow that dilution is protecting the finance, effort and creative talent that has been invested in producing the mark itself and its personality in the marketplace.

While it is true, however, that anti-dilution remedies may only be invoked by owners of famous or distinctive marks, the fundamental proposition that dilution is recognition of the intrinsic value of the mark is not negated. It has been observed that the famousness requirement is not more than a common sense reflection on the fact that a common type or little-known mark is in fact inherently diluted and the presence of another similar mark could hardly affect the negligible public perception of the original mark. ${ }^{35}$ It is not denied that non-famous marks have an intrinsic value, it is merely submitted that they have not yet reached such a position in the marketplace to be capable of suffering the harm represented by dilution. The ability to invoke the anti-dilution remedy is recognition of a trade mark fulfilling its potential to become an asset of value to its registered owner.

The development of the dilution doctrine is recognition in law of the distance the trade mark has come in the last century. However, it will be argued below that the efficacy of the dilution remedy in its current form must being questioned in light of the novel and unconventional claims for trade mark protection increasingly coming before the courts.

33 Elizabeth Cutter Bannon "Revisiting "The Rational Basis of Trademark Protection:" Control of Quality and Dilution - Estranged Bedfellows?" (1990) 24 The John Marshall Law Review 65, 90.

34 Bannon, above n 33, 91-2. 


\section{DOMAIN NAME DISPUTES: UNCONVENTIONAL TRADE MARK CLAIMS, THE COURTS' RESPONSE AND THE FALL-OUT}

The Internet has created new opportunities for businesses to expand into international markets in ways never before possible. Companies are anxious to exploit this new tool by establishing web sites promoting and selling their wares. Trade marks play an integral role in Internet commerce, not only on the web sites themselves. Trade marks make very effective domain names. This new use of trade marks as domain names has given rise to a new, challenging breed of trade mark disputes between trade mark owners and those who have illegitimately registered the formers' trade marks as domain names. The aggrieved trade mark owners usually combat the offending use of their trade marks by way of an action for trade mark infringement and for dilution of trade mark. This is not without problems.

This section will discuss the tension between the domain name and the trade mark. The main case law relating to domain name disputes and the impact of these decisions on the trade mark function will be analysed.

\section{A The Internet and Domain Name Disputes}

\section{Background}

Every web-site on the Internet has an address. Web-sites are currently addressed using the domain name system.

Domain names are arranged so that reading from right to left, each part of the name points to a more localised area of the Internet. For example, in the domain name "acme.com", "com" is the top level domain name signifying the commercial nature of the enterprise. "Acme" specifies the second level domain name, a set of networks used by the company Acme. There may be only one registration of the domain name "acme.com". ${ }^{36}$ Each country will normally have a domain name registrar, that an organisation which will manage the registration of domain names. In New Zealand, domain name registrations are managed by "Domainz", the New Zealand Internet Registry. These organisations generally work on a first come, first served basis; they will not determine an applicant's right to register any given domain name.

Users may access a web-site either directly, by using the domain name, or by searching for the site using the search engines available on the Internet. There is no Internet equivalent to a telephone directory and searching through the use of key terms may be time consuming and fruitless. It is, therefore, to the advantage of a company wishing to

36 For concise discussions of the Internet Protocol number and domain name systems see Avery Dennison, above $\mathrm{n} 23$ and Panavision, above $\mathrm{n} 31$. 
trade on the Internet to register a domain name which is memorable to the consumer and which reflects as closely as possible the name of their business. A company's trade mark will invariably fulfil this function. Disputes occur when a registered trade mark owner finds his or her trade mark has been registered as a domain name by someone else, who may or may not have a legitimate interest in doing so. There are broadly three types of fact scenarios which may give rise to a dispute. The first situation is commonly known as "cybersquatting". This is where someone with entrepreneurial designs registers a wellknown trade mark, to which they have no legitimate right, as a domain name, with the intention of selling it back to the owner of the trade mark. The second situation involves the registration of a trade mark by somebody with genuinely competing rights. The third type of dispute occurs where someone registers a trade mark as a domain name with the intention of using the site for political propaganda. ${ }^{37}$ The instinctive reaction of an aggrieved trade mark owner is to pursue an action on the basis of trade mark misuse. The problems with this approach are discussed below.

\section{Trade marks $v$ domain names}

There is a tension inherent in applying traditional trade mark law to resolve domain name disputes. Domain names are not trade marks. They will normally serve merely a nominative function; they may operate as trade marks however. There has been some judicial dissension as to when domain names will operate as trade marks. In Lockheed Martin Corporation v Network Solutions Inc ${ }^{38}$ [Lockheed Martin] District Judge Pregerson held that something more than the registration of the name is required before the use of trade mark as a domain name is infringing. Other courts, however, have sought to extend protection to a broader range of cases. For example, in Panavision $v$ Toeppen ${ }^{39}$, perhaps the best known American cybersquatting case, the Court seemed to ignore any issue as to whether the defendant was using the plaintiff's trade mark as a trade mark, focussing simply on whether or not Toeppen's use of the trade mark fulfilled the requirement of the statute that the use be "in commerce". If the reasoning of the court in Lockheed Martin is correct, the validity of any proceedings for trade mark infringement in cases of trade mark piracy or pure cybersquatting must be questioned. It can be observed, however, that if the

37 This particular type of case will not be discussed in detail in this paper, but see for example Planned Parenthood Federation of America Inc v Bucci (1998) 42 USPQ 2d 1430 (9th Cir), where the plaintiff was a well-known, non-profit organisation offering birth control advice and was targeted by a religious radio show host who registered the plaintiff's name as a domain name with the admitted intention of attracting users to it and delivering them an anti-abortion message.

38 Lockheed Martin Corporation v Network Solutions Inc (1997) 985 F Supp 949 (CD Cal) [Lockheed Martin].

39 Panavision, above $\mathrm{n} 31$. 
Courts are providing relief in these situations, they are looking beyond the traditional trade mark function of denoting the source of goods, to recognising an intrinsic value in the mark which requires protection. The tension between domain names and trade marks is best illustrated through the relevant case law, an analysis of which is set out below.

\section{The case law}

(a) The United States

In the United States registered and suitably qualified unregistered trade marks, are protected against infringement, unfair competition and dilution by the federal Lanham Act. ${ }^{40}$ There are some remedies available at the common law, ${ }^{41}$ but most of the litigation concerning domain names in the United States has been decided under the infringement and dilution provisions of the Lanham Act. A key element of proving an action under the Lanham Act, whether for conventional infringement or dilution, is demonstrating that the offending use of the trade mark was "in commerce".

The leading case in the United States is Panavision $v$ Toeppen. The case concerned a cybersquatter who registered as domain names many famous trade marks, including Panavision's "panavision" and "panaflex" trade marks. When issued with a "cease and desist" letter by Panavision, Toeppen offered to settle the matter for an extortionist sum. An action was brought by Panavision under the dilution provisions of the Lanham Act. ${ }^{42}$ The court noted that the case required it to consider the novel issue of interpreting the Federal Trademark Dilution Act as it applies to the Internet. ${ }^{43}$

The court found that in order to prove a violation of the Federal Trade Mark Dilution Act a plaintiff must show that: 44

(1) the mark is famous;

(2) the defendant is making a commercial use of the mark in commerce;

(3) the defendant's use began after the mark became famous;

40 Lanham Act 15 USC § 1125.

41 Such as unfair competition, misappropriation, common law infringement and common law "palming off".

42 The Lanham Act was amended by the Federal Dilution Act 1996 to include anti-dilution provisions.

43 Panavision, above $\mathrm{n} 31,1318$.

44 Panavision, above n 31, 1324. 
(4) the defendant's use of the mark dilutes the quality of the mark by diminishing the capacity of the mark to identify and distinguish goods and services;

Toeppen contended that his use of Panavision's trade marks simply as domain names could not constitute a commercial use under the Act. He further argued that a domain name is simply an address used to locate a web page: a user who types in $<$ panavision.com> but who sees no reference to the plaintiff Panavision is not likely to conclude the web page is related in any way to Panavision. ${ }^{45}$

The court found, however, that Toeppen had acted as a spoiler for Panavision; that is, his conduct prevented Panavision from doing business on the Internet under their trade marked name. Further, the court found that Toeppen's attempt to sell the trade marks themselves was a commercial use. ${ }^{46}$

The court also found that Toeppen's conduct had caused dilution of Panavision's trade marks. It stated that it no longer needed to rely on traditional definitions of dilution, such as "blurring" and "tarnishment". ${ }^{47}$ In this case, it found that Toeppen's conduct had diminished the capacity of the Panavision marks to identify and distinguish Panavision's goods and services on the Internet. Further, Toeppen's use of <panavision.com> put Panavision's name and reputation at his mercy. It could potentially be associated with an unimaginable amount of messages on Toeppen's web page. Moreover, the court found that potential customers of Panavision would be discouraged if they were not able to find its web page by typing in <panavision.com>. ${ }^{48}$

The court's decision is susceptible to some criticism. Firstly, it does not stop to consider whether Toeppen's use of Panavision's trade mark was in fact use as a trade mark. It would appear that the court assumed that it was use as a trade mark, or alternatively, disregarded it as a requirement and leapt straight to a consideration of whether it was a commercial use "in commerce". It is certainly arguable that Toeppen's use of Panavision's trade marks was not "use as a trade mark". A user who visited Toeppen's <panavision.com> website was merely presented with a landscape picture and the phrase "Welcome to Pana, Illinois'. It was not used to identify the source of products.

The second aspect of the judgment which may be criticised is the finding that the use was "in commerce". As Paul Sumpter stated in a recent article "While this [requirement] does not necessitate evidence of actual sales of goods or services (or advertising them), the

45 Panavision, above $\mathrm{n} 31,1324$.

46 Panavision, above n 31, 1325.

47 Panavision, above n 31, 1326.

48 Panavision, above n 31, 1327. 
use, as the statutory wording makes clear, should be in a commercial setting where some goods or services are sold, distributed or advertised". ${ }^{49}$ Assistance may be gained by reference to the "in commerce" requirement in the provisions regarding direct infringement, pursuant to which the plaintiff must demonstrate that the defendant must have used the mark "in connection with the sale, offering for sale, distribution or advertising of any goods or services". If this is the correct interpretation of the requirement that the use be in "commerce" then it is clear that the court in Panavision took an incredibly broad approach in finding it fulfilled in this case.

A similar approach was taken in another case involving the exploits of Mr Toeppen: Intermatic Incorporated $v$ Toeppen. ${ }^{50}$ Intermatic involved a very similar fact scenario to Panavision. Mr Toeppen registered the domain name <intermatic.com> intending to sell the registration back to Intermatic. The court found that Toeppen's intention to arbitrage the <intermatic.com> domain name constituted a commercial use: "Toeppen's desire to resell the domain name is sufficient to meet the "commercial use" requirement of the Lanham Act". ${ }^{51}$ Further, his use of the Internet satisfies the "in commerce"requirement: ${ }^{52}$

Because Internet communications transmit instantaneously on a worldwide basis there is little question that the "in commerce" requirement would be met in a typical Internet message, be it trademark infringement or false advertising.

Again the issue of whether or not Toeppen's use of Intermatic's trade mark constituted use as a trade mark was ignored by the court.

The liberal stance adopted by the court in Panavision and Intermatic can be contrasted with the approaches taken by the courts in two more American domain name cases. In the first, Lockheed Martin Corporation v Network Solutions Inc, ${ }^{53}$ Lockheed Martin, owner of the trade mark "SKUNK WORKS", sued Networks Solutions, an American domain name registrar, alleging infringement, unfair competition, dilution and contributory infringement under the Lanham Act in connection with Networks Solutions' conduct in accepting domain name registrations that were identical or similar to Lockheed's SKUNK WORKS service mark. When considering the "use in commerce" requirement of the trade

49 Paul Sumpter "When are Domain Names Trade Marks - When They Are 'Used'?: Unfair Reapers in Cyberspace Get the Common Law Treatment" (2000) 11 AIPJ 103.

50 Intermatic Incorporated v Toeppen (1996) 947 F Supp 1227 (Nd Ill).

51 Intermatic, above $\mathrm{n} 50,1239$.

52 Gilson Trademark Protection and Practice, s 5.11[2], 5-234 (1996), quoted in Intermatic, above n 50, 1239

53 Lockheed Martin, above n 38, 949. 
mark infringement provisions of the Lanham Act, the court, unlike that in Panavision, considered whether the use was use as a trade mark. It concluded that when a domain name is used only to indicate an address on the Internet, the domain name is not functioning as a trade mark. Domain names, like trade names, do not act as trade marks when they are used merely to identify a business entity; in order to infringe they must be used to identify the source of goods or services. Something more than the registration of the name is required before the use of a domain name is infringing. ${ }^{54}$

It is submitted, however, that the reasoning in Lockheed Martin must not be taken out of context. It has to be questioned whether there were more fundamental policy considerations behind the decision, especially regarding the desirability of finding domain name registrars liable for trade mark infringement in respect of domain name registrations. Another consideration in assessing the weight to be given to this decision for the purpose of the present analysis is that NSI's conduct in accepting domain name registrations is fundamentally different from the conduct of a cybersquatter like Dennis Toeppen. The "sharp practice" which the courts were seeking to redress in Panavision and Intermatic was not present here. NSI was not trading off the good name of the SKUNK WORKS mark, nor was it using it for extortionist purposes. It was merely fulfilling its designated role as a domain name registrar. As it was reasoned by the court in Lockheed Martin: ${ }^{55}$

NSI's acceptance of domain name registrations is connected only with the names' technical function on the Internet to designate a set of computers. By accepting registrations of domain names containing the words "skunk works," NSI is not using the SKUNK WORKS mark in connection with the sale, distribution or advertising of goods and services...This is the type of purely "nominative" function that is not prohibited by trademark law.

On this basis, it is possible to make a distinction between this case and Panavision.

The second case to take a stricter approach to the "in commerce" requirement was Avery Dennison Corporation $v$ Sumpton. Avery Dennison sells office products and industrial fasteners under the registered trademarks "Avery" and "Dennison," respectively. "Avery" has been in continuous use since the 1930s and registered since 1963, and "Dennison" has been in continuous use since the late 1800s and registered since 1908. Avery Dennison maintains a commercial presence on the Internet, marketing its products at <avery.com> and <averydennison.com>, and maintaining registrations for several other domain-name combinations, all using the top level domain <.com>. Sumpton was the president of Freeview, an Internet e-mail provider doing business as "Mailbank." Mailbank offered "vanity" e-mail addresses to users for a fee and had registered thousands of domain-name

54 Lockheed Martin, above n 38, 957.

55 Lockheed Martin, above n 38, 957. 
combinations for this purpose. Mailbank's surname archives include the domain name combinations <avery.net> and < dennison.net>. Avery Dennison brought an action against Internet e-mail provider and its president, alleging federal and state claims of trademark infringement, trademark dilution, and unfair competition in registering "avery.net" and "dennison.net" as Internet domain names and licensing them as e-mail addresses.

Avery Dennison failed to jump several of the hurdles in establishing their claim in the Court of Appeals. The court found that their marks were not sufficiently distinctive to attract protection against dilution ${ }^{56}$ and further, that there was not sufficient evidence that Freeview's use had caused dilution. ${ }^{57}$ However, the most important finding for the purposes of this discussion was that Freeview's use was not use as a trade mark and was not a "commercial use" for the purposes of the Lanham Act: 58

All evidence in the record indicates that Appellants register common surnames in domain-
name combinations and license e-mail addresses using those surnames, with the consequent
intent to capitalise on the surname status of "Avery" and "Dennison." Appellants do not use
trademarks qua trademarks as required by the case law to establish commercial use. Rather,
Appellants use words that happen to be trademarks for their non-trademark value. The
district court erred in holding that Appellants' use of <avery.net> and <dennison.net>
constituted commercial use under the Federal Trademark Dilution Act, and this essential
element of the dilution causes of action likewise mandates summary judgment for Appellants.

Thus, American courts are divided in their approach to domain name disputes. Whether or not a pattern may be discerned in relation to the evolution of the trade mark function will be discussed below.

(b) Britain

The leading case in Britain to deal with this issue is British Telecommunications Plc $v$ One in a Million $L t d^{59}$ The defendant had registered a large number of Internet domain names comprising the names or trade marks of well known commercial or other enterprises without their consent. The defendants claimed that they had registered the domain names with a view to making a profit either by selling them to the owners of the goodwill or to collectors or other persons who could have a legitimate reason for using them. Relief was sought both under passing off and trade mark infringement. The trade mark cause of

56 Avery Dennison, above n 23, 876-7.

57 Avery Dennison, above n 23, 879.

58 Avery Dennison, above n 23, 880.

59 British Telecommunications Plc v One in a Million Ltd [1999] 1 WLR 903 (CA) [One in a Million]. 
action was argued under section 10(3) of the Trade Marks Act 1994 (UK), which provides: 60

A person infringes a registered trade mark if he uses, in the course of trade a sign which-

(a) is identical with or similar to the trade mark; and

(b) is used in relation to goods or services which are not similar to those for which the trade mark is registered, where the trade mark has a reputation in the United Kingdom and the use of the sign being without due cause, takes unfair advantage of, or is detrimental to, the distinctive character or the repute of the trade mark.

While the court for the most part considered the claim for passing off. ${ }^{61}$ Aldous J did make some interesting observations in relation to the issue of trade mark infringement. His comments have been described as "tantalisingly short"62 and while they probably raise more questions than they answer, they do suggest some broadening of approach in relation to the circumstances in which the courts will find infringement and invoke protection. In particular, Aldous LJ stated that he was "not satisfied that section 10(3) does require the use to be trade mark as use nor that it must be confusing use". ${ }^{63}$ Such a statement lends support to the notion that section 10(3) may be available to suppress any use of the mark which may harm the plaintiff's mark, without the need to show confusion. The decision looks remarkably similar to the American decisions in Panavision and Intermatic.

\section{(c) New Zealand}

The major cases in New Zealand to deal with the issue of domain name piracy have been decided under the common law remedy of passing off and the Fair Trading Act. ${ }^{64}$ It is interesting to note, however, that New Zealand retains, in the Trade Marks Act 1953, the requirement that for a mark to infringe it must be through "use as a trade mark". 65

60 Trade Marks Act 1994 (UK), s 10(3). This provision is regarded as opening the door to a cause of action for dilution of a trade mark.

61 Indeed the case was decided under passing off.

62 Sumpter, above $\mathrm{n} 49,111$.

63 One in a Million, above n 59, 926 (however, he was prepared to assume that this was the case).

64 Oggi Advertising v McKenzie [1999] NZLR 631 and New Zealand Post v Leng [1999] 3 NZLR 219.

65 Trade Marks Act 1994, s 8(1A)(d). Section 8(1A)(e) provides that where use of a trade mark upon goods or in or in physical relation to goods an advertising circular imports a reference to some person having the right either as proprietor or as a registered user to use the trade mark or to goods with which such a person is connected in the course of trade, such a use will be an infringing use. While importing a reference may not strictly constitute "use as a trade mark", such 
The fact that the New Zealand decisions have been made under these alternative causes of action is perhaps due to the fact that New Zealand does not have an equivalent dilution remedy. ${ }^{66}$ Famous trade marks may still in part be protected from the harm caused by dilution through a system of defensive registration. Section 36 of the Trade Marks Act 1953 allows proprietors of famous trade marks to register their marks in relation to goods or services, other than those in respect of which the mark was originally registered, as a defensive trade mark. This system means that trade mark owners may prevent the use of their famous marks on unrelated products, even if they have no intention of trading in those areas themselves.

This system, however, does not operate to provide the same coverage as the antidilution provisions. It requires the positive acts of the trade mark owner of identifying the goods or services, against which use of the trade mark may have the potential to cause confusion, and registering the trade mark in respect of those goods or services. The system recognises the potential for the use of famous marks on non-competing products to be confusing, but doesn't recognise the value of the mark itself, and that mere use on a noncompeting product may cause harm to that mark. The focus, again, appears to be on consumer confusion.

\section{B Are the Domain Name Cases Changing the Trade Mark Function?}

The issue is contentious. Some commentators believe that due to the inconsistency of the decisions thus far there is no clear pattern of change. ${ }^{67}$ Whether the flexible response of the courts is leading to a more generous attitude towards famous brands and the consequential reshaping of trade mark law, some claim, is too early to tell. Sumpter, in a recent article, claimed that "when confronted with new circumstances of trade mark misuse there may be a natural inclination toward pragmatism". ${ }^{6} \mathrm{He}$ is of the view that whilst Judges are willing to be "light on their feet" in the face of new technologies and their exploitation through sharp business practices, the domain name cases, so far, reveal no hint of any dramatic directional change in trade mark law. ${ }^{69}$

a use of a trade mark still involves exploiting the trade mark's source denoting function. This can be distinguished from using the trade mark in a purely nominative sense, such as, as a domain name.

66 Although see Sumpter, above n 49, 113. Sumpter claims that an anti-dilution remedy is available in New Zealand under passing off.

67 Sumpter, above n $49,110$.

68 Sumpter, above $\mathrm{n} 49,110$.

69 Sumpter, above n 49, 113-4. 
Sumpter's view can be contrasted with that of Giorgio Vergani. In an analysis of the "use in commerce" requirement in the trade mark context, he argues that the extreme interpretation of the requirement given by the courts is just a small piece of a bigger change in the trade marks field: "This change is shifting the focus of the trade marks' function from traditional consumer protection toward a concept that is more close to property, allowing the trade mark owner a much broader protection...". ${ }^{70}$ Vergani made a number of conclusions, the following being relevant for the present discussion: ${ }^{71}$

... The "use in commerce" interpretation given in the electronic commerce context, if followed by other decisions of the same kind, especially in the "real world", could lead to a revolution in the conception of trade marks themselves. This interpretation would shift the traditional trade mark function from the "consumer protection theory" to a "property right theory", where a trade mark is valuable, even in the absence of consumer confusion or association with goods or services, per se. The simple fact that owning an unused domain name is deemed to be "in commerce"... or even that the non-commercial use of a domain name is "commercial use in commerce" as any use on the Internet is automatically a use "in commerce" shows how the courts have stretched the trade marks doctrine so that the association with a product or service is not required to qualify a name as a trade mark, either to find "use in commerce" of the same mark or to infringe another's trade mark rights... .

One of the factors Vergani cites as evidence of this new function is the recent approval of the Federal Trademark Dilution Act (1995) which protects famous marks for potentially all products, regardless of consumer confusion. ${ }^{72}$ This observation is especially pertinent given the approach to the dilution provisions taken by the courts in Panavision and Intermatic.

The present author is of the opinion that it is not sufficient to dismiss the recent case law lowering the threshold for trade mark protection as inconsistent and not representative of a shift in the trade mark function. It is submitted that the very fact that the courts are willing to extend the protection in cases where someone has simply registered another's trade mark as a domain address is representative of the fact that a famous mark is worth protecting against use by those without any legitimate interest, even when that use is not "as a trade mark" according to traditional conceptions. Further, as discussed above, the court in One in a Million went as far as to state explicitly that use as a

70 Giorgio Nicolò Vergani "Electronic Commerce and Trade Marks in the United States: Domain Names, Trade Marks and the 'Use in Commerce Requirement' on the Internet" [1999] EIPR 450, 450 .

71 Vergani, above n 70, 460.

72 Vergani, above n 70, 460. 
trade mark and proof of confusion may not be prerequisites to invoking relief under the British anti-dilution provisions. It is submitted that, contrary to the notion that there is no intrinsic worth in a trade mark, that is exactly what the courts, in these decisions, are seeking to protect. The appropriateness of these decisions in terms of the existing framework of trade mark protection, and indeed the adequacy of the framework in this modern age will be questioned below.

\section{INADEQUACY OF THE CURRENT FRAMEWORK AND POSSIBLE REFORM ${ }^{73}$}

The issues that arise in domain name disputes are symptomatic of the trend towards a need for increased trade mark protection. It is suggested that this trend will not be confined to domain name cases. Dilution appears to be the way of the future in this regard, as it recognises that any use of a famous mark, regardless of whether that use causes confusion, may be injurious to that mark. However, as it has been demonstrated above, the courts are struggling to provide increased protection within the confines of the present legislative framework. This section will examine the efficacy of the current dilution legislation. The courts' approach to the legislation will be taken as indicative of whether the framework is robust enough to respond adequately to the need for increased protection. The discussion will primarily concern whether the decisions in Panavision and Intermatic can be justified within the present legislative provisions.

\section{A The United States: The Lanham Act and the Federal Dilution Act}

Trade mark protection in the United States is principally administered under the Lanham Act. ${ }^{74}$ The Lanham Act was amended in 1996 by the Federal Trademark Dilution Act to include anti-dilution provisions. The purpose of the Lanham Act has been held to be to provide national protection of trade marks to secure to the owner of the mark the goodwill of his business and to protect the ability of consumers to distinguish between competing producers. ${ }^{75}$

The amendment made by the Federal Dilution Act provides an avenue for owners of famous marks to attack offending uses of the mark which cause dilution of the distinctive quality of the mark. ${ }^{76}$ The action also carries the requirement that the use of the mark be

73 This section of the paper will consider the legislative framework in the United States, as that country is the source of most of the case law which is seeking to extend trade mark protection beyond the traditional bounds.

74 Each State also has individual statutory laws.

75 Advanced Resources Intern Inc v Tri-Star Petroleum Co C.A.4 (Va) (1993) 4 F 3d 327. See Part IV above for a description of the requirements of the Lanham Act.

76 For a detailed description of the action, see above under Panavision and generally in Part IV. 
"commercial use in commerce". The dilution doctrine does, to a certain extent, recognise that a trade mark may have an intrinsic value worthy of protection. However, the courts' current interpretive approach is significant of the fact that the provisions do not comfortably accommodate the new types of action increasingly coming before the courts. This assertion is supported by the decisions in Panavision and Intermatic where the language of the section had to be twisted in order for the court to provide relief.

As noted above, the anti-dilution provisions retain the requirement that the offending use of the plaintiff's trade mark be "in commerce". This element of the action has proved to cause the courts some difficulty when faced with novel trade mark claims, such as those seen in the domain name disputes.

In Panavision, having dismissed the defendant's argument that the simple act of registering a trade mark as a domain name does not constitute a commercial use, the court found the "in commerce" requirement met. Toeppen's use of Panavision's mark, trading on its value and preventing Panavision from doing business on the Internet under its trade marked name, did indeed constitute a commercial use. Further, the court found that Toeppen's attempt to sell the trade marks was a commercial use.

This interpretation is plainly beyond the scope of the provision. As a threshold point, the use of Panavision's mark by Toeppen is arguably not use as a trade mark. The issue that has concerned most commentators, however, is the court's approach to the "use in commerce" requirement. ${ }^{77}$

However, the overriding sentiment discernible in Panavision and Intermatic is that there has been a wrong committed and the courts are willing to strain the requirements of the statute to achieve a "just" outcome for the aggrieved trade mark owner. Such a desire to achieve justice and recognise the commercial value of a trade mark is not misplaced, it is an indication of the growing acceptance that trade marks are deserving of protection in their own right. Trade mark law ought to accommodate this notion. The law as it currently stands is not equipped to deal with such cases. The courts should not have to struggle with the law as they have been doing. As illustrated by Panavision and similar cases, this is leading to a piecemeal development of the law with no clear policy directive. This in turn leads to unsatisfactory and inconsistent results and a lack of certainty for trade mark owners. Additionally, the trade mark function is becoming increasingly indefinite. ${ }^{78}$

77 See for example, Sumpter, above n 49 and Vergani, above n 70 The "in commerce" requirement has been stretched even further in cases involving organisations which register domain names to make political, social or religious statements.

78 See also the approach of the court in One in a Million, above $\mathrm{n} 59$, to the anti-dilution provisions in the UK trade mark legislation. The non-committal statements made by Aldous LJ serve to 


\section{B Anti-cybersquatting Legislation}

\section{The Anti-cybersquatting Consumer Protection Act}

Partly in response to these cases, the United States has introduced legislation specifically aimed at punishing cybersquatters. The Anti-Cybersquatting Amendment Act ("the ACPA") amends the Lanham Act to add a new section, section 43(d)(1)(A). It applies to "any existing and future alphanumeric designation which is registered with or assigned by any domain name registry, or other domain name registration authority as part of an electronic address on the Internet." It provides trade mark owners with a civil remedy against cybersquatting. Under the ACPA, courts can issue injunctions and order cancellation or transfer of the offending domain names. In addition, trade mark owners may elect to seek statutory damages, instead of actual damages and profits, of $\$ 1000$ to $\$ 100,000$ per domain name, as determined by the court, for any domain name registered on or after 29 November 1999, in violation of the ACPA.

Liability arises under the ACPA where somebody registers a domain name which is identical or confusingly similar to another's distinctive trade mark, or that dilutes another's famous trade mark. The ACPA focuses on the intellectual property rights in the contested mark and the extent to which the registrant acted in bad faith with the intent to mislead consumers or profit from the registration of the domain name. ${ }^{79}$

\section{Does this legislation provide the answer?}

The ACPA certainly clarifies the situation in relation to cybersquatting and the circumstances in which a cybersquatter will infringe the rights of a trade mark owner. However, it is strongly arguable that by introducing a sui generis "quick-fix" cause of action under the umbrella of the Lanham Act, the legislature have not only side stepped the more fundamental issues identified above, it may have created further confusion.

Implicit in the ACPA is recognition of the fact that while domain name piracy should not ordinarily fit within the trade mark infringement provisions, it does cause harm to the trade mark. However, this is overshadowed due to the emphasis the Act places on the "bad faith" requirement. Like the court in Panavision, the ACPA focuses on the need to redress a wrong where there is evidence of sharp practice, and ignores the inevitable byproduct of the reasoning: there was a wrong committed because the trade mark is valuable

illustrate the point that it is not certain whether the anti-dilution provisions best equip the courts to deal with domain name disputes.

79 The ACPA provides nine non-exclusive factors which the Court may consider to determine whether or not the cybersquatter acted in bad faith: see 15 USC $§ 1125$ 
and should be protected even against uses which would not traditionally be considered to infringe.

Furthermore, the ACPA does not address the more general expansion of the trade mark function. Liability under the Act arises only where a domain name registrant registers another's trade mark as a domain name with the bad faith intent to profit from that registration.

As Kelly and Hieber state "The Act basically adopts the law as fashioned by those federal courts that have grappled with the issues in a legislative vacuum". 80 Given the incongruous nature of the results in Panavision and other domain name cases, this is an unsatisfactory stop-gap measure which will render the trade mark function more indecipherable and will create a body of trade mark law peculiar to these types of cases.

\section{Reform}

As concluded above, the current legislative regimes dealing with trade mark infringement and protection are not adequate to deal with the modern trade mark function and the novel forms of infringement increasingly coming before the courts. The fact the courts are required to consider new trade mark issues is indicative of the need for reform of trade mark legislation. This section will propose some changes to the legislation which, it is submitted, would enable trade mark owners to invoke the proper protection of their valuable marks. ${ }^{81}$ These changes would not require a substantial redrafting or reformulation of any existing legislation. However, some major concessions relating to the theory of trade marks would have to be made.

The dilution doctrine is a very useful tool in dealing with the modern trade mark function and the corresponding injuries. The doctrine would form the basis of the proposed changes. However, the requirement of the United States anti-dilution provisions that the use of the trade mark be a "commercial use in commerce" restrains the proper application of the section. The requirement that the offending use of the trade mark be use "as a trade mark" is also misplaced. It is difficult to see how these requirements are relevant to a remedy that seeks to protect the trade mark from blurring or tarnishment or a reduction in the ability of the mark to distinguish the owner's goods. Any use of a mark, whether it is in commerce, or use as a trade mark, must surely have the potential to be

80 David M Kelly \& Christina J Hieber: "Taking Aim at Cybersquatters - a new weapon for US trademark owners" (March 2000) Trademark World Issue No 125 14, 15.

81 These changes will be based on the United States trade mark legislation, specifically the antidilution provisions. However, it is proposed that such changes would be appropriate in the legislation of other countries with similar trade mark legislation, including New Zealand. 
injurious to a trade mark in this manner. The present author proposes that these requirements be removed from the dilution provisions.

It is submitted that these changes would create "true" anti-dilution provisions. Implicit in the changes is the notion that trade marks are capable of suffering an injury from many kinds of offending uses, aside from those acts traditionally considered to infringe trade mark rights. The changes further recognise that the trade mark has progressed from merely serving a consumer-protection function to being capable of being of considerable value to the trade mark owner.

Given the broad approach suggested above, it would be necessary to impose some restrictions on the application of the anti-dilution remedy, particularly to prevent trade mark rights being exploited to create monopolies or suppress freedom of expression. It is proposed that certain fair use defences be included in trade mark legislation for this purpose. The risk inherent in granting greater protection rights in trade marks is discussed in Section VI below.

\section{THE DESIRABILITY OF A SHIFT IN THE TRADE MARK FUNCTION AND BROADER PROTECTION}

It is the fundamental proposition of this paper that the trade mark is evolving. Rather than resist this development, the law should meet it and not shy from extending to trade marks the proper amount of protection. This is not the only view however. There are some who believe that it is improper to allow the trade mark to expand beyond its traditional confines. Further, there are some fundamental policy considerations which may negate the further development of the trade mark.

Schechter, in 1927, asserted that "obsolete conceptions both as to the function of the trade mark and the need for its protection" need be abandoned in favour of the "proper expansion" of trade mark law. ${ }^{82}$ He claimed that if we continue to proceed on the assumption that a trade mark's proper function is to designate either origin or ownership, the law, even in its most liberal interpretation, will prevent the misuse of that mark only where there is actual confusion created by such misuse, resulting in either diversion of trade or injury to trade repute. ${ }^{83}$ As noted above, Schechter was the first great advocate for protecting trade marks from dilution. His proposition that trade mark law should be extended to recognise injury by dilution was founded on the theory that the value of a trade mark depended in large part upon its uniqueness and that the identity and the hold upon the public mind of the mark may be gradually whittled away by its use on non-

82 Schechter, above $\mathrm{n} 12,824$.

83 Schechter, above $\mathrm{n} 12,825$. 
competing goods. Indeed, Schechter's theory was that this is the only rational basis for the protection of trade marks, and that the conception that a trade mark is solely a designation of source is not only to misconstrue the proper trade mark function, but to prevent the development of the true trade mark function and consequently its proper protection.

Conversely, there is a reluctance to acknowledge, much less approve the expanding trade mark function and the corresponding broader protection. Pickering discounts the protection of trade marks for their intrinsic worth as irrelevant. He compares a trade mark with human physical integrity, to which such worth is attached that we have laws criminalising any form of offence against the person. He claims that it is not realistically possible to argue that "a producer in using a trade mark creates a symbol of such novelty, charged with such meaning that it must without derogation be defended against unauthorised interference". ${ }^{84}$ It is the present author's view that the distinction between human physical integrity and trade marks is unhelpful in this analysis. Acknowledging that a trade mark is capable of being intrinsically valuable and is susceptible to a wider variety of harm than previously accepted and seeking to restrain uses which unjustifiably harm or trade off the value of the mark is quite different to protecting a person from violation through the criminal law. Further, it is submitted that to make a claim that a trade mark is incapable of being charged with meaning is to underestimate the ability of a trade mark to gain a secondary meaning, so that the trade mark is so distinctive that it may be used by the owner of the mark as a tradeable commodity or to forge into new markets.

Pickering, however, is not alone in his views. In the 1995 United Kingdom case of Wagamama. ${ }^{85} \mathrm{Mr}$ Justice Laddie took the opportunity to discuss the trade mark function. Having decided that the essential function of the mark is "to give the consumer or final user a guarantee of the identity of the origin of the marked product by enabling him to distinguish, without any possible confusion, that product from others of a different provenance", he went on to assert that if a broader scope were to be adopted it would be to create a new type of monopoly not related to the proprietor's trade but in the trade mark itself. $^{86}$ He claimed that such a monopoly could be likened to a quasi-copyright in the mark: "However, unlike copyright, there would be no fixed duration for the right and it would be a true monopoly effective against copyist and non-copyist alike". ${ }^{87}$ It is submitted that this view is self-perpetuating. It dismisses at the outset the fundamental point that it is conceivable that trade marks are capable of achieving a status where one

84 Pickering, above n 3, 95.

Wagamama Ltd v City Centre Restaurants Plc and Another [1995] FSR 713.

86 The broader scope Mr Justice Laddie is referring to is protection against non-origin association.

Wagamama, above n 85. 
company should have a sole right to its use, or at least the ability to restrain conduct which is injurious to the mark.

There has further been discussion as to whether the trade mark is moving towards being recognised as a property right in gross. It is easy to make the leap between recognising that a trade mark is capable of having an intrinsic worth to thinking of a trade mark as conferring inalienable rights. However, fundamental questions must be posed as to the desirability of such a move. In a recent lecture, Professor David Vaver discussed the trend towards the reification of intellectual property rights. ${ }^{88} \mathrm{He}$ asserted that there is a danger inherent in this trend, leading to situations where intellectual property rights are permitted to trump over fundamental human rights such as freedom of speech and freedom of expression. This type of situation is easily foreseeable in the trade mark arena, indeed there have been cases where owners of famous trade marks have sued parodists for infringement.

A United States case involving the famous "Coca-Cola" trade mark illustrates this dilemma. ${ }^{89}$ The owners of the "Coca-Cola" trade mark, the soft drink manufacturing company, moved for a preliminary injunction to restrain defendant from further sale of a poster generated by the defendant, which consisted of an exact blown-up reproduction of the plaintiff's familiar trademark and distinctive format. The defendant had made a substitution of the script letters in the trademark, which encouraged people to "Enjoy Cocaine". The court found that the real thrust of the plaintiff's claim was that unless the defendant's unauthorised use of the "Coca-Cola" trade mark and format was enjoined, the plaintiff's good will and business reputation was likely to suffer in the eyes of those, who, believing it to be responsible for the defendant's poster, would refuse to deal with a company which would seek commercial advantage by treating a dangerous drug in such a jocular fashion. ${ }^{90}$ The plaintiff further argued that the defendant's poster impinged directly on its own advertising use of the mark in a manner which creates confusion and is likely to cause injury to the plaintiff even though that may not be their intent. The defendant's contention was that "the poster was intended to be a spoof, satirical, funny, and to have a meaning exactly opposite of the word content". 91 The defendant's also sought to defend their poster as an instance of free expression, secured by the First Amendment, which constituted fair comment and could not be defamatory without a claim of malice. The court found for the plaintiff on that basis that, while there may not

88 David Vaver, "Intellectual Property: the State of the Art" (2001) 32 VUWLR 1.

90 Coca-Cola Co, above n 89, 1191.

91 Coca-Cola, above n 89, 1187. 
have been confusion of goods or passing off in the strict trade mark sense, there was a sufficiently clear showing of the impairment of the plaintiff's mark as a selling device due to the defendant's use. As to the claim of free expression, the court found that the thrust of the plaintiff's claim was against the defendant's imitative use of the trade mark. It stated that the Lanham Act recognises that even newspapers, magazines and periodicals may be enjoined from innocent infringement of another's mark as to future publication. ${ }^{92}$

It is submitted, with respect, that this is a case where trade mark protection has been taken too far. It is not difficult to understands Coca-Cola's position in objecting to the defendant's use of their trade mark, but it does not necessarily follow that it is a use which should be restrained. Given the omni-present nature of trade marks in modern society it is hardly surprising that, as one commentator has written, "trademarks [sic] have become a natural target of satirists who seek to comment on this integral part of the national culture". 93 In this case, there was no question of the defendant trading off the good name of the plaintiff; while they certainly made money from the venture, it was clearly a parody of the plaintiff's mark and there was a very low risk of consumer confusion. It is submitted that the court did not adequately address the freedom of expression aspect of the case. Despite the obvious value of the "Coca-Cola" trade mark and indeed other marks of comparable status, there must be a balance achieved between protecting the value of these marks and allowing parodists and others to have their say.

While it is clearly not desirable to allow the trade mark to be used to create monopolies or to take precedence over fundamental human rights such as freedom of expression, it is submitted that to deny broader protection on this basis is to restrict unnecessarily the expansion of the trade mark function. It is the present writer's view that the trade mark has evolved, and will continue to evolve beyond the traditional function of designation of source and that such development should not be resisted. It should be possible to acknowledge the need for greater trade mark protection and avoid the "evils" inevitably associated with it. The changes to the legislation proposed in section IV above, that is to remove the "commercial use in commerce" requirement and the requirement that the use be "as a trade mark", would, it is submitted, achieve this delicate balance.

92 Coca-Cola, above $\mathrm{n} 89,1192$. Another example of a case where a parody has been found to infringe trade mark owners' marks is LL Bean Inc v Drake Publishers Inc (1987) 811 F 2d 26 (1st Cir) where the defendant magazine parodied the plaintiff's famous catalogue by displaying a facsimile of Bean's trade mark and features pictures of nude models in sexually explicit positions. The court disposed of the first amendment concerns in this way: "Plaintiff's trademark is in the nature of a property right... and as such it need not yield to the exercise of First Amendment rights under circumstances where adequate alternative avenues of communication exist".

93 Harriet Dorsen "Satiric Appropriation and the Law of Libel, Trademark and Copyright: Remedies without Wrongs" (1986) 65 BUL Rev 923, 939. 


\section{CONCLUSION}

The twentieth century has experienced more technological advance than any before it. "Mass communication" is a buzz-word with radio, television, bill-board advertising and the Internet having a daily involvement in our lives. Producers have seized upon this phenomenon and new forms of promotion, advertising and marketing are constantly being pursued and employed. In this environment the trade mark is an indispensable tool. It is in this environment that the trade mark has come of age.

However, there has been a broad resistance to acknowledging the worth of the modern trade mark and consequently the courts are left with legislation inadequate to deal with the demand for increased protection. The development of the dilution doctrine has in part accepted that trade marks are capable of suffering injuries which reflect their inherent value. However, in its current legislative form, dilution cannot operate to its full extent.

The domain name cases illustrate this dilemma. In these cases the courts have recognised that a wrong has been committed and have wrestled with the legislation to achieve a just result. These decisions have been put down to pragmatism, but it is the submission of this paper that implicit in these decisions is the fact that the trade mark is valuable, independent of the goods upon which it is used.

It is submitted that dilution may be the answer, but with some changes. The changes proposed in this paper would remove the "in commerce" requirement from the antidilution provisions. Further, it would not longer be a requirement of the provisions that the offending use be "as a trade mark". It is suggested that there should be defences to a claim for dilution of trade mark, with a fair use focus.

What Schechter described in 1927 as "the proper expansion of the trade mark" 94 should not be resisted. It is possible to acknowledge that a trade mark should be protected for its inherent worth and, at the same time, prevent the abuse of such privileges.

94 Schechter, above n $12,824$. 
